\title{
Can species Cedrela fissilis Vell. be used in sites contaminated with toxic aluminum and cadmium metals?
}

\author{
Caroline Castro Kuinchtner, \\ Gerâne Silva Wertonge de Oliveira, \\ Marcos Vinicius Miranda de Aguilar, \\ Daniele Bernardy, \\ Mirian Berger, \\ Luciane Almeri Tabaldi
}

\begin{abstract}
Toxic metals are among the main pollutants contributing to environmental degradation. Cadmium (Cd) and aluminum (Al) stand out among these metals as extremely toxic elements. The use of native species in reforestation programs can compensate for degradation and re-establish the ecological conditions of the affected environments. Cedrela fissilis Vell., popularly known as cedar, may be used as an alternative in phytoremediation, since it is a fastgrowing native woody species widely distributed in tropical America. In this study we investigated the possibility of using $C$. fissilis in sites contaminated with $\mathrm{Al}$ and $\mathrm{Cd}$ by evaluating morphological, physiological, and biochemical variables of seedlings grown in hydroponic system. $C$. fissilis seedlings were subdivided into two experiments with a completely randomized design. The first experiment evaluated the effect of four Al concentrations, namely: 0 (complete nutrient solution without phosphorus), 25, 50 and $100 \mathrm{mg} \mathrm{l}^{-1}$. The second experiment evaluated four $\mathrm{Cd}$ concentrations, namely: 0 (complete nutrient solution), 25, 50 and $100 \mu \mathrm{M}$. Each sample unit consisted in a pot with four plants. Morphological, physiological and biochemical variables of seedlings were evaluated after 15-day exposure to different treatments in the hydroponic system. Aluminum concentration of $100 \mathrm{mg} \mathrm{l}^{-1}$ caused oxidative stress in $C$. fissilis seedlings, reduced shoot and root dry weight, and increased hydrogen peroxide contents, which led to lipid peroxidation. Cadmium concentration of $100 \mu \mathrm{M}$ also damaged $C$. fissilis seedlings by significantly reducing root dry weight and involving the most severe effects on photosynthetic variables. Cadmium presence in the nutrient solution negatively affected morphophysiological and biochemical variables of Cedrela fissilis seedlings, and it was also harmful to their growth. Based on our results, the investigated species shows a sensitive behavior upon exposure to cadmium. On the other hand, $C$. fissilis tolerates high Al concentrations (up to $50 \mathrm{mg} \mathrm{l}^{-1}$ ), which suggests a moderate tolerance to this metal.
\end{abstract}

Keywords: Phytoremediation, Heavy Metals, Gas Exchange, Morphophysiological Variables

low concentrations (Cunha Neto et al. 2020).

Cadmium is widespread in different environments and is extremely toxic to plants and animals (Hassan et al. 2020). It is mainly released into the environment through human activities such as mining, metallurgy, cement factories, waste combustion and use of pesticides and fertilizers com-

prising Cd (Huang et al. 2017). Although Cd mium (Cd) and aluminum ( $\mathrm{Al})$ are potentially toxic to different organisms even at
Departamento de Biologia, Universidade Federal de Santa Maria, Av. Roraima 1000, Cidade Universitária Bairro - Camobi, Santa Maria-RS,97105-900 (Brasil)

@ Luciane Almeri Tabaldi (lutabaldi@yahoo.com.br)

Received: Jun 01, 2021 - Accepted: Aug 27, 2021

Citation: Castro Kuinchtner C, Silva Wertonge de Oliveira G, Miranda de Aguilar MV, Bernardy D, Berger M, Tabaldi LA (2021). Can species Cedrela fissilis Vell. be used in sites contaminated with toxic aluminum and cadmium metals? iForest 14: 508-516. - doi: 10.3832/ ifor3890-014 [online 2021-11-11]

Communicated by: Werther Guidi Nissim is not essential for plant nutrition, it can be easily absorbed by roots and accumulated in all plant tissues, from roots to shoot. Average $\mathrm{Cd}$ rate in Brazilian soils seen as uncontaminated is $0.18 \mathrm{mg} \mathrm{Kg}^{-1}$, whereas contaminated soils worldwide present $\mathrm{Cd}$ content ranging from 5.9 to $531 \mathrm{mg} \mathrm{Kg}^{-1}$, depending on the cause of pollution (Kubier et al. 2019).

The main Cd-induced toxicity symptoms observed in plants comprise stunted growth, chlorosis, leaf epinasty, abnormal chloroplast ultrastructure, photosynthesis inhibition, enzyme inactivation in $\mathrm{CO}_{2}$ fixation processes, lipid peroxidation, disturbance in nitrogen and sulfur homeostasis, biological membrane oxidation and reduced root and stem growth, and concomitant reduction in biomass production (Anjum et al. 2017).

Aluminum is one of the most abundant metals on Earth's crust (Zhou et al. 2017). Its toxicity is one of the biggest limitations to plant yield in acidic soils in tropical and subtropical sites worldwide (Cunha Neto et al. 2020). Brazilian soils are mostly weath- 
ered and acidic due to high Al and manganese $(\mathrm{Mn})$ contents, as well as to low sum and saturation of bases (Cunha et al. 2018). These soils show $\mathrm{pH}<5.0$; under these conditions, $\mathrm{Al}$ is ionized to form phytotoxic ions $\left(\mathrm{Al}^{3+}\right)$ that are promptly absorbed by plant roots, thus inhibiting root elongation and reducing crop yield (Guo et al. 2018). Since amelioration processes are hard to accomplish and highly expensive, soil acidity has become a major issue in subsurface soils; therefore, it is necessary to find crop plant species capable of tolerating acidic soils or high $\mathrm{Al}$ accumulation rates.

Root growth inhibition - which may occur after brief plant exposure to $\mathrm{Al}$ - is the first symptom of Al toxicity. Root meristems are considered the plant part most sensitive to Al toxicity, suggesting that $\mathrm{Al}$ actively interacts in cell division and elongation processes (Cárcamo et al. 2019). Plants' response to exposure to $\mathrm{Al}$ are associated with changes in physiological and biochemical processes, such as increased reactive oxygen species (ROS) production and damage to biological membranes. In addition, Al has negative effects on photosynthetic activity, such as decreased photosynthetic pigments and fluorescence parameters, reduced enzyme activity and carbohydrate metabolism, decreased stomatal conductance, and programmed cell death induction (Xu et al. 2018).

Given the harmful effect of these metals on plant components, it is essential to identify species capable of tolerating such contamination or accumulating these metals though time in order to revegetate and/or even decontaminate contaminated sites (Yan et al. 2020). Also, it is necessary understanding the mechanisms developed by tolerant and resistant plants to support the selection of species suitable to be used in sites contaminated with toxic metals.

Cedrela fissilis Vell. (cedar) stands out among several species with potential to recover degraded areas (Silva et al. 2020). This native woody species grows fast and is widely distributed in tropical America. C. fissilis has light and soft timber, which can be easily used for several purposes, such as plywood, moldings, sculptures, civil construction and as ornamental species (Goetten et al. 2016). In addition, it presents high biomass production and filtering capacity, due to its extensive root system, which are features highly desirable for phytoremediation programs (Covre et al. 2020).

The aim of the present study is to investigate the suitability of $C$. fissilis to be used in remediation of areas contaminated with $\mathrm{Al}$ and $\mathrm{Cd}$, by evaluating morphological, physiological and biochemical variables in hydroponic system.

\section{Material and methods}

\section{Study site}

The study was conducted in a greenhouse at the Biology Department of Fed- eral University of Santa Maria (UFSM), Santa Maria Campus, RS, Brazil, under controlled temperature of approximately 25 ${ }^{\circ} \mathrm{C}$, and mean humidity of $60 \%$. Analyses were carried out at the Plant Physiology and Nutrition Laboratory of the Biology Department.

\section{Experimental design}

Cedrela fissilis seedlings were subdivided into two experiments, which followed a completely randomized design. The first experiment evaluated the effect of four aluminum (Al) concentrations: 0 (complete nutrient solution without phosphorus), 25 , 50 and $100 \mathrm{mg} \mathrm{L}^{-1}$. Control treatment had nutritive solution without phosphorus $(P)$ to avoid physical-chemical interactions between $\mathrm{P}$ and Al. The second experiment evaluated four cadmium ( $\mathrm{Cd}$ ) concentrations: o (complete nutrient solution), 25, 50 and $100 \mu \mathrm{M}$. Each sample unit consisted in a pot with four plants. The above $\mathrm{Cd}$ and $\mathrm{Al}$ concentrations were selected based on the scientific literature and on studies conducted by our research group with other plant species.

Seeds purchased in the UFSM Forest Nursery, Santa Maria Campus, were used to produce $C$. fissilis seedlings. They were sown in Carolina Soil ${ }^{\circledast}$ commercial substrate composed of Sphagnum sp. and vermiculite. Plastic trays $(38 \times 56 \mathrm{~cm})$ were used as containers for seedling germination and initial growth. Substrate humidity was kept close to $60 \%$ of the field capacity and monitored on a daily basis throughout the experimental period.

Seedlings were irrigated with complete nutrient solution at $\mathrm{pH} 4.5 \pm 0.1$ on a weekly basis, from the $15^{\text {th }}$ day after sowing (DAS) onwards. Nutrient solution was formed by $6090.5 \mu \mathrm{M}$ of nitrogen $(\mathrm{N})$; 974.3 $\mu \mathrm{M}$ of magnesium (Mg); $4986.76 \mu \mathrm{M}$ of chlorine (Cl); $2679.2 \mu \mathrm{M}$ of potassium (K); $2436.2 \mu \mathrm{M}$ of calcium (Ca); $359.9 \mu \mathrm{M}$ of sulfur (S); $243.592 \mu \mathrm{M}$ of phosphorus (P); $0.47 \mu \mathrm{M}$ of copper (Cu); $2.00 \mu \mathrm{M}$ of manganese $(M n) ; 1.99 \mu M$ of zinc (Zn); $0.17 \mu M$ of nickel (Ni); $24.97 \mu \mathrm{M}$ of boron (B); 0.52 $\mu \mathrm{M}$ of molybdenum (Mo) and $47.99 \mu \mathrm{M}$ of iron (as $\mathrm{FeSO}_{4} / \mathrm{Na}$-EDTA - Hoagland \& Arnon 1950).

Seventy-three days after sowing, when seedlings were approximately $10 \mathrm{~cm}$ tall, they were carefully removed from the substrate in the trays and transferred to hydroponic system. Each seedling was placed in a 6-L pot filled with Hoagland \& Arnon (1950) complete nutrient solution. Polystyrene blade with four central holes was added to the surface of each pot to allow plants to pass through it. The polystyrene blade allowed plants to be fixed and reduced the solution evaporation from each pot.

Seedlings were left to acclimate for seven days in Hoagland's nutrient solution, at $100 \%$ of its original concentration. Nutrient solution in each pot was aerated through PVC microtubes connected to air compres- sor. Its original form comprised the following concentrations (in $\mathrm{mg} \mathrm{L}^{-1}$ ): $\mathrm{NO}_{3}=196$; $\mathrm{NH}_{4}=14 ; \mathrm{P}=31 ; \mathrm{K}=234 ; \mathrm{Ca}=160 ; \mathrm{Mg}=$ 48.6; $\mathrm{S}=70 ; \mathrm{Fe}-\mathrm{EDTA}=5 ; \mathrm{Cu}=0.02 ; \mathrm{Zn}=$ $0.15 ; \mathrm{Mn}=0.5 ; \mathrm{B}=0.5 ; \mathrm{Mo}=0.01$.

After the acclimation period, seedlings were subjected to treatments based on different $\mathrm{Al}$ and $\mathrm{Cd}$ availability conditions for 15 days; they remained in hydroponic system for 22 days, in total. Plants were collected as soon as metal toxicity symptoms were observed, mainly at the highest $\mathrm{Al}$ and $\mathrm{Cd}$ concentrations. Nutrient solution in each pot was replaced twice a week and its $\mathrm{pH}$ was adjusted on a daily basis to $4.5 \pm$ 0.1 using $1.0 \mathrm{~mol} \mathrm{~L}^{-1} \mathrm{HCl}$ or $1.0 \mathrm{~mol} \mathrm{~L}^{-1} \mathrm{NaOH}$.

\section{Growth variables}

One plant from each experimental unit was collected for growth assessment purposes. Shoot height and root length of each seedling were measured by a millimeter ruler. Measurements were taken before and after treatment application, and plant growth derived from the increase recorded within that period.

Seedlings were harvested and separated into shoots and roots, washed in running water and dried in forced air circulation oven at approximately $65{ }^{\circ} \mathrm{C}$, until they reached constant weight. Shoot (SDW, g plant ${ }^{-1}$ ) and root dry weight (RDW, g plant $\left.{ }^{-1}\right)$ were determined.

Roots were subjected to morphological characterization based on digitized images using the software WinRhizo ${ }^{\mathrm{TM}}$ Pro 2013 (Regent Instruments Inc., Sainte-Foy, Quebec, Canada) coupled to a scanner Expression $11000^{\oplus}$ (EPSON Corp., Nagano, Japan) equipped with additional light (TPU) at 600 DPI resolution. Root length ( $\mathrm{cm}$ plant $\left.{ }^{-1}\right)$, mean root diameter $(\mathrm{mm})$ and number of branches were measured.

\section{Photosynthetic variables}

The third fully expanded leaf of each seedling was used to evaluate photosynthetic variables in an infrared gas analyzer (model Li-COR ${ }^{\circledast} 6400 \mathrm{XT}$, Lincoln, NE, USA) at $500 \mu \mathrm{mol}$ photosynthetic radiation ${ }^{-2} \mathrm{~s}^{-1}$ and $\mathrm{CO}_{2}$ concentration of $400 \mu \mathrm{mol} \mathrm{mol}{ }^{-1}$. Measurements were carried out in the morning between 8:00 and 10:00 am, before plants were collected for growth analysis. The following variables were determined: net $\mathrm{CO}_{2}$ assimilation rate $(A)$, transpiratory rate $(E)$, stomatal conductance (Gs), intercellular $\mathrm{CO}_{2}$ concentration $\left(C_{i}\right)$, Rubisco's instant carboxylation efficiency $\left(A / C_{i}\right.$, based on the ratio between photosynthetic rate and intercellular $\mathrm{CO}_{2}$ concentration), and water use efficiency (WUE, based on the ratio between photosynthetic and transpiration rates).

\section{Biochemical variables}

Twelve plants from each treatment were collected and subjected to biochemical variable analysis, totaling 48 plants per experiment. Seedlings were separated into shoot and roots, washed in distilled water, 
placed in aluminum foil envelopes, and frozen with liquid nitrogen to avoid sample degradation. They were kept in ultra-freezer at $-80{ }^{\circ} \mathrm{C}$ until they were pre-prepared for analysis. Sample preparation was carried out through manual maceration with liquid nitrogen until a fine powder was obtained for each sample. Subsequently, the specific amount of powder necessary for each analysis was weighted using a precision digital scale: $0.05 \mathrm{~g}$ of fresh sample was used for determining leaf pigments, $0.5 \mathrm{~g}$ for antioxidant enzymes, $0.3 \mathrm{~g}$ for hydrogen peroxide, and $0.5 \mathrm{~g}$ for lipid peroxidation.

\section{Total chlorophylls and carotenoids content}

The Hiscox \& Israelstam (1979) method was used for total chlorophyll and carotenoid extraction, whereas the Lichtenthaler (1987) equation was used for their estimates. Previously weighed samples were added with $5 \mathrm{ml}$ of dimethylsulfoxide (DMSO). Tubes were incubated at $65^{\circ} \mathrm{C}$ for approximately $90 \mathrm{~min}$, until full pigment release in a dark green solution was achieved. Subsequently, this solution was separated into two repetitions of $2 \mathrm{ml}$ each. Solution absorbance was measured in UV-visible spectrophotometer (model 1105, Bel Photonics, Piracicaba, Brazil), at wavelength of 663,645 and $470 \mathrm{~nm}$ for chlorophyll $a$, chlorophyll $b$ and carotenoids, respectively. Total chlorophyll values corresponded to the sum of chlorophylls $a$ and $b$.

\section{Antioxidant enzyme activity}

Antioxidant enzymes were determined by adding $0.5 \mathrm{~g}$ of sample to $3 \mathrm{~mL}$ of 0.05 $\mathrm{M}$ homogenization extraction buffer $(\mathrm{pH}$ 7.8) comprising $1 \mathrm{mM}$ EDTA and $2 \%(\mathrm{w} / \mathrm{v})$ polyvinylpyrrolidone (PVP). Homogenate was centrifuged in a high-speed refrigerated centrifuge (model CR22 N, Eppendorf Himac Technologies Co., Hitachinaka, Japan) at $13,000 \times \mathrm{g}$ at $4{ }^{\circ} \mathrm{C}$ for 20 minutes. Supernatant was used to determine enzyme activity and protein concentration (Zhu et al. 2004).

Guaiacol peroxidase (POD) enzyme activity was determined according to Zeraik et al. (2008); guaiacol was used as substrate. Reaction mixture comprised $1.0 \mathrm{ml}$ of potassium phosphate buffer $(100 \mathrm{mM}, \mathrm{pH}$ 6.5), $1.0 \mathrm{ml}$ of guaiacol ( $15 \mathrm{mM}$ ) and $1.0 \mathrm{ml}$ of $\mathrm{H}_{2} \mathrm{O}_{2}(3 \mathrm{mM})$ in quartz cuvette. When the homogenization was complete, $50 \mu \mathrm{L}$ of plant extract was added to the solution. Enzyme activity was measured through guaiacol oxidation into tetraguaiacol by increasing absorbance at $470 \mathrm{~nm}$ at 15 -second reading intervals. Results were expressed in enzyme units per $\mathrm{mg}$ of protein $\left(\mathrm{U} \mathrm{mg} \mathrm{m}^{-1}\right.$ protein). The molar extinction coefficient of $26.6 \mathrm{mM}^{-1} \mathrm{~cm}^{-1}$ was used for calculation purposes.

Superoxide dismutase (SOD) activity was determined based on the spectrophotometric method described by Giannopolitis
\& Ries (1977). Reaction mixture (MIX), which was kept in the dark, comprised 50 $\mathrm{mM}$ of potassium phosphate buffer $(\mathrm{pH}$ 7.8), $13 \mathrm{mM}$ of methionine, $0.1 \mathrm{mM}$ of EDTA, $75 \mu \mathrm{M}$ of nitrobluetetrazolium (NBT) and $2 \mu \mathrm{M}$ of riboflavin. Photochemical production of blue formazan from NBT was monitored by increasing absorbance at 560 $\mathrm{nm}$. Reaction process was carried out at 25 ${ }^{\circ} \mathrm{C}$ in test tubes $(13 \times 100 \mathrm{~mm})$ filled with 2.8 $\mathrm{ml}$ of reaction mixture (MIX) and $200 \mu \mathrm{l}$ of enzymatic extract from the respective samples. After pipetting, tubes were placed in the reaction chamber under $15 \mathrm{~W}$ fluorescent lamp. Reaction started when the light was turned on and stopped 2 minutes later, when the light was turned off; samples were read in UV-visible spectrophotometer. SOD unit was defined as the number of enzymes inhibiting NBT photoreduction by $50 \%$ (Beauchamp \& Fridovich 1971). During the test, photochemically excited riboflavin was reduced by methionine in semiquinone, which donated an electron to oxygen and formed the superoxide radical, which in turn converted NBT into blue formazan. Superoxide dismutase has catalyzed this reaction.

\section{Hydrogen peroxide content}

Hydrogen peroxide content was determined according to Loreto \& Velikova (2001). Root and leaf samples were homogenized in $3.0 \mathrm{~mL}$ of $0.1 \%$ trichloroacetic acid (TCA). Homogenized samples were centrifuged, $0.5 \mathrm{ml}$ of the supernatant was added to $0.5 \mathrm{ml}$ of potassium phosphate buffer $(10 \mathrm{mM})$ and $1 \mathrm{ml}$ of $\mathrm{KI}(1 \mathrm{M})$, and samples were absorbed in spectrophotometer at $390 \mathrm{~nm} . \mathrm{H}_{2} \mathrm{O}_{2}$ concentration in the supernatant was evaluated by comparing its readings to a standard calibration curve. $\mathrm{H}_{2} \mathrm{O}_{2}$ concentration was expressed as $\mu \mathrm{mol} \mathrm{g}{ }^{-1}$ fresh weight.

\section{Membrane lipid peroxidation}

Lipid peroxidation was determined based on malondialdehyde (MDA) concentration, based on the method by El-Moshaty et al. (1993). Leaf and root samples were homogenized in $4.0 \mathrm{~mL}$ of sodium citrate buffer ( $\mathrm{pH}$ 6.5) and centrifuged. In total, 1 $\mathrm{ml}$ of supernatant was added to $1 \mathrm{ml}$ of $20 \%$ $(\mathrm{w} / \mathrm{v})$ trichloroacetic acid (TCA) added with $0.5 \%(w / v)$ thiobarbituric acid (TBA). The mix was heated to $95{ }^{\circ} \mathrm{C}$ for $40 \mathrm{~min}$ and cooled in ice bath for $15 \mathrm{~min}$. Subsequently, it was centrifuged at $10,000 \times \mathrm{g}$ for $15 \mathrm{~min}$ utes. Supernatant absorbance was read at 532 and $600 \mathrm{~nm}$ (to correct non-specific turbidity). Lipid peroxidation was expressed as nmol of MDA mg-1 protein.

\section{Statistical analysis}

Results were subjected to analysis of variance, based on the factorial model (factorial ANOVA). Significant differences were checked by F-test and treatment means compared by Tukey test $(\alpha=0.05)$ using the Sisvar statistical software (Ferreira 2014).

\section{Results}

\section{Cadmium effects on Cedrela fissilis}

ANOVA results showed significant differences ( $p \leq 0.05)$ among $C d$ treatments (different cadmium concentrations) for most growth-related morphological variables in C. fissilis seedlings reared in a hydroponic system. Cd concentrations of 50 and 100 $\mu M$ promoted a significant reduction in root length increment (ILR - Fig. 1A), while seedlings grown at $\mathrm{Cd}$ concentration of 25 $\mu M$ did not show difference in ILR in comparison to control $(0 \mu \mathrm{M} \mathrm{Cd})$. On the other hand, C. fissilis seedlings did not show significant difference in increment in shoots (IS) regardless of the tested concentrations (data not shown).

Cadmium concentrations of 25, 50 and $100 \mu \mathrm{M}$ had negative effects on shoot dry weight (SDW - Fig. 1C) and root dry weight (RDW - Fig. 1B), in comparison to the control treatment. Seedlings exposed to 100 $\mu \mathrm{M}$ of $\mathrm{Cd}$ had the shortest mean root length (Fig. 1D), as well as the smallest diameter (Fig. 1E) and number of branches (Fig. 1F). However, there was no significant difference in root volume at all tested $\mathrm{Cd}$ concentrations (data not shown).

Different $\mathrm{Cd}$ concentrations had significant effect $(p \leq 0.05)$ on most physiological variables analyzed in the present study. Net $\mathrm{CO}_{2}$ assimilation rate ( $A$ - Fig. $2 \mathrm{~A}$ ), stomatal conductance (Gs - Fig. 2B) and transpiration rate ( $E$ - Fig. $2 C$ ) showed significant decrease as $\mathrm{Cd}$ concentrations in the nutrient solution increased. The highest $\mathrm{Cd}$ concentration treatment $(100 \mu \mathrm{M})$ had the most negative effects on the aforementioned parameters.

Cadmium concentration of $100 \mu \mathrm{M}$ had the most significant effect on internal $\mathrm{CO}_{2}$ concentration ( $C_{i}-$ Fig. 2D). Cadmium levels of 0 and $25 \mu \mathrm{M}$ were statistically similar in terms of both internal $\mathrm{CO}_{2}$ concentration (Fig. 2 D) and water use efficiency (WUE data not shown). On the other hand, $\mathrm{Cd}$ treatments at 50 and $100 \mu \mathrm{M}$ recorded the highest mean WUE in comparison to other treatments (data not shown). However, there was no significant difference between treatments on Rubisco carboxylation efficiency $\left(A / C_{i}\right.$ - data not shown), regardless of the tested concentrations.

Different $\mathrm{Cd}$ concentrations had a significant effect $(p \leq 0.05)$ on most biochemical variables analyzed in this study. Total chlorophyll increased at $\mathrm{Cd}$ concentration of $50 \mu \mathrm{M}$ (Fig. 2E), whereas an increased content in carotenoids was found at $\mathrm{Cd}$ concentrations of 25 and $50 \mu \mathrm{M}$ (Fig. 2F).

A significant increase in the activity of superoxide dismutase (SOD) in the shoot of C. fissilis seedlings was detected when $\mathrm{Cd}$ concentration in the nutrient solution increased (Tab. 1). SOD activity reached the highest values at $\mathrm{Cd}$ concentrations of 50 and $100 \mu \mathrm{M}$, i.e., an increase by $37 \%$ in shoot at $100 \mu \mathrm{M}$. SOD activity increase by $10.83 \%$ was observed in the roots at $\mathrm{Cd}$ concentration of $100 \mu \mathrm{M}$, in comparison to the 

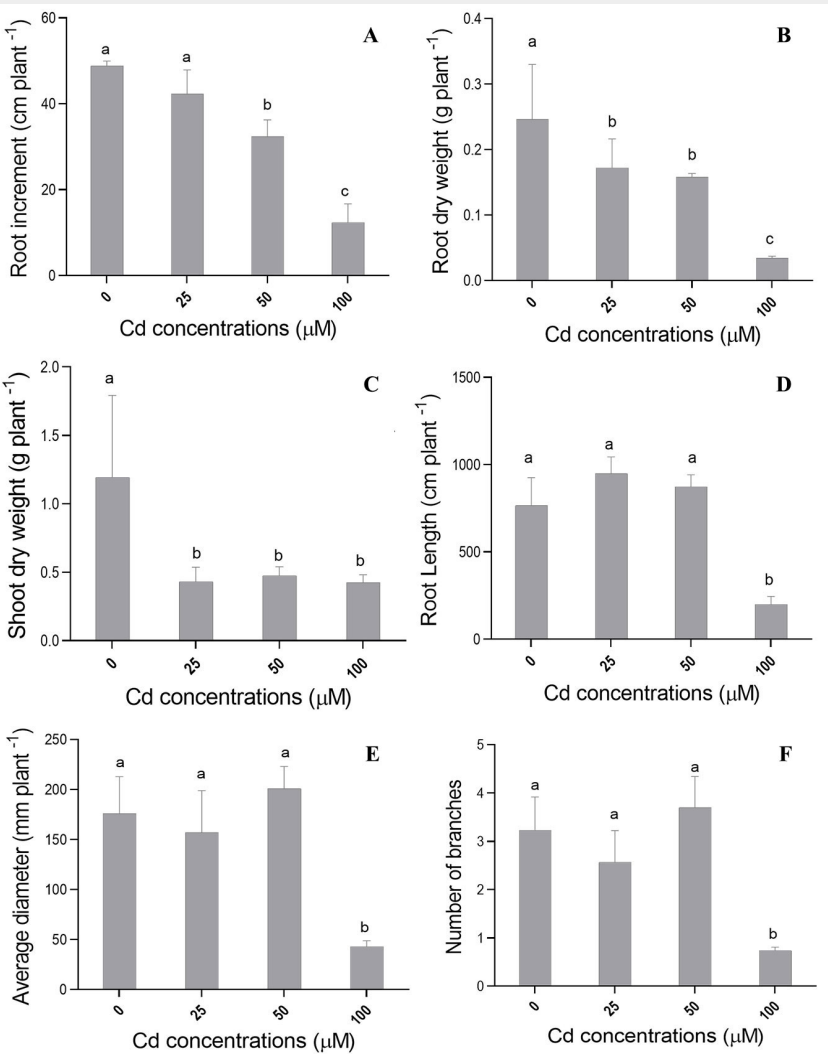

Fig. 1 - Mean values recorded for (A) largest root length increment (ILR), (B) root dry weight (RDW), (C) shoot dry weight (SDW), (D) root length, (E) root diameter and (F) number of branches in $C$. fissilis seedlings subjected to different $C d$ concentrations. Bars represent the mean \pm standard deviation. Different lowercase letters indicate significant $(p \leq 0.05)$ differences between treatment means after Tukey test.
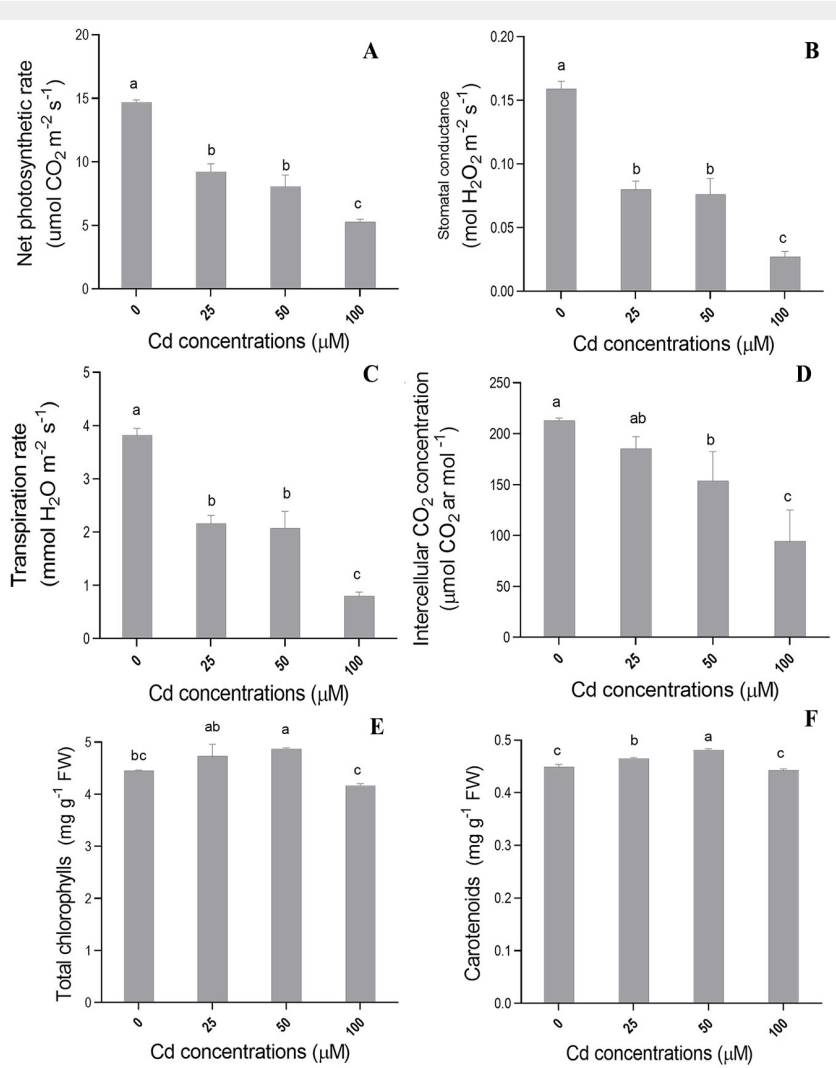

Fig. 2 - Mean values recorded for (A) net photosynthetic rate, (B) stomatal conductance (Gs), (C) transpiration, (D) intercellular $\mathrm{CO}_{2}$ concentration $\left(\mathrm{C}_{\mathrm{i}}\right)$, (E) total chlorophyll (total $\mathrm{Chl}$ ) and (F) carotenoids in $C$. fissilis seedlings subjected to different $\mathrm{Cd}$ concentrations. Bars represent the mean \pm standard deviation. Different lowercase letters indicate significant $(p \leq 0.05)$ differences between treatment means after Tukey test. control treatment (Tab. 1).

The highest values recorded for guaiacol peroxidase (POD) activity in the shoots were observed in seedlings subjected to $\mathrm{Cd}$ concentrations of 25,50 and $100 \mu \mathrm{M}$, which were significantly different from those recorded in control plants (Tab. 1). Contrastingly, a significant reduction in POD activity in roots was observed at the same Cd concentrations (25, 50 and $100 \mu \mathrm{M}$ - Tab. 1).

A significant increase in hydrogen perox- ide $\left(\mathrm{H}_{2} \mathrm{O}_{2}\right)$ content in the shoot was detected at $\mathrm{Cd}$ concentrations of 50 and 100 $\mu \mathrm{M}$ (Fig. $2 \mathrm{~A}$ ). On the other hand, $\mathrm{H}_{2} \mathrm{O}_{2}$ content in the shoot and roots were similar ( $p>0.05$ ) at $C d$ concentrations of 25 and 0 $\mu \mathrm{M}$. However, there was negative correlation between $\mathrm{H}_{2} \mathrm{O}_{2}$ content and $\mathrm{Cd}$ concentration in the roots ( Tab. 1), since $\mathrm{H}_{2} \mathrm{O}_{2}$ content decreased at $\mathrm{Cd}$ concentrations of 50 and $100 \mu \mathrm{M}$, in comparison to the control seedlings.
Lipid peroxidation values in the shoot at Cd concentrations of 25, 50 and $100 \mu \mathrm{M}$ were higher than those recorded in the control plants (Tab. 1). On the other hand, lipid peroxidation in the roots at $\mathrm{Cd}$ concentrations of 25 and $100 \mu \mathrm{M}$ was higher when compared with that in control seedlings (Tab. 1).

Aluminum effects on Cedrela fissilis Analysis of variance revealed significant

Tab. 1 - Mean values recorded for superoxide dismutase (SOD) enzyme activity, guaiacol peroxidase enzyme (POD) activity, hydro gen peroxide content, and membrane lipid peroxidation in the shoot and roots of $C$. fissilis seedlings subjected to different $C d$ concentrations. Data represent the mean \pm standard deviation. Different letters in rows indicate significant $(p \leq 0.05)$ differences between treatment means after Tukey test.

\begin{tabular}{|c|c|c|c|c|c|}
\hline \multirow{2}{*}{ Variable } & \multirow{2}{*}{ Compartment } & \multicolumn{4}{|c|}{ Treatment (Cd concentration) } \\
\hline & & $0 \mu \mathrm{M}$ & $25 \mu \mathrm{M}$ & $50 \mu \mathrm{M}$ & $100 \mu \mathrm{M}$ \\
\hline \multirow{2}{*}{$\begin{array}{l}\text { SOD activity } \\
\text { (U } \mathrm{mg}^{-1} \text { protein) }\end{array}$} & Shoot & $327.2 \pm 4.5^{c}$ & $351.6 \pm 18^{b c}$ & $418.3 \pm 23.0^{\mathrm{b}}$ & $524.5 \pm 6.4^{\mathrm{a}}$ \\
\hline & Root & $338.3 \pm 27^{b}$ & $322.7 \pm 20.1^{b}$ & $315.7 \pm 17.7^{b}$ & $379.3 \pm 23.7^{\mathrm{a}}$ \\
\hline \multirow{2}{*}{$\begin{array}{l}\text { POD activity } \\
\text { (U mg } \text { mprotein) }^{-1} \text { prote }\end{array}$} & Shoot & $80.3 \pm 10.3^{c}$ & $177.8 \pm 5.6^{b}$ & $253.4 \pm 7.6^{a}$ & $235.9 \pm 10.5^{a}$ \\
\hline & Root & $1358.6 \pm 10.8^{a}$ & $774.7 \pm 23.6^{b}$ & $736.4 \pm 32.9^{b}$ & $510.3 \pm 0.6^{c}$ \\
\hline \multirow{2}{*}{$\begin{array}{l}\mathrm{H}_{2} \mathrm{O}_{2} \\
\left(\mu \mathrm{mol} \mathrm{g}{ }^{-1} \mathrm{FW}\right)\end{array}$} & Shoot & $0.86 \pm 0.02^{b}$ & $0.91 \pm 0.02^{b}$ & $1.0 \pm 0.01^{\text {a }}$ & $1.04 \pm 0.05^{\mathrm{a}}$ \\
\hline & Root & $0.17 \pm 0.02^{a}$ & $0.18 \pm 0.01^{a}$ & $0.13 \pm 0.01^{b}$ & $0.0 \pm 0.01^{c}$ \\
\hline \multirow{2}{*}{$\begin{array}{l}\text { MDA } \\
\text { (nmol mg }{ }^{-1} \text { protein) }\end{array}$} & Shoot & $0.05 \pm 0.01^{c}$ & $0.10 \pm 0.02^{a}$ & $0.07 \pm 0.0^{b}$ & $0.07 \pm 0.0^{b}$ \\
\hline & Root & $0.03 \pm 0^{c}$ & $0.08 \pm 0.001^{a}$ & $0.05 \pm 0.0 \mathrm{bc}$ & $0.05 \pm 0.0^{b}$ \\
\hline
\end{tabular}



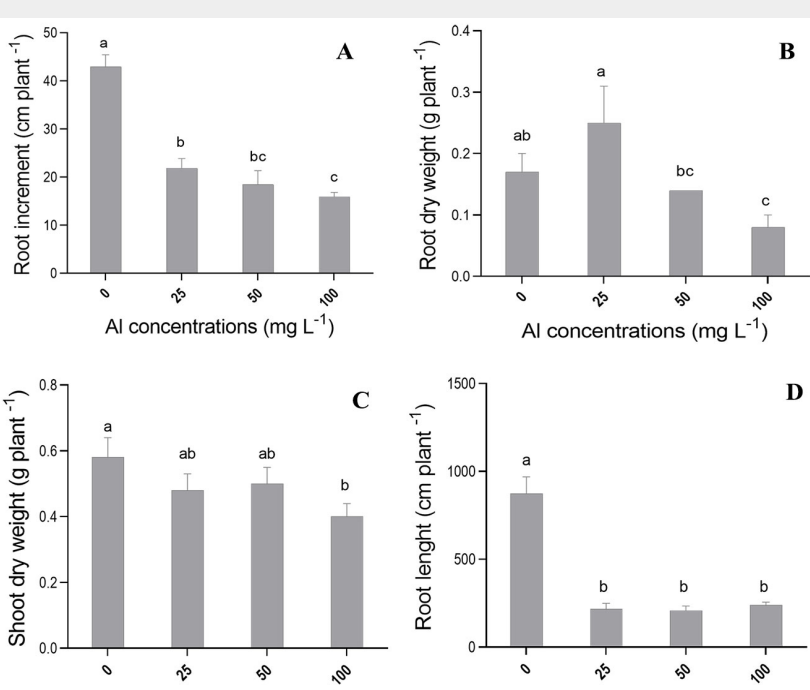

Al concentrations $\left(\mathrm{mg} \mathrm{L}^{-1}\right)$
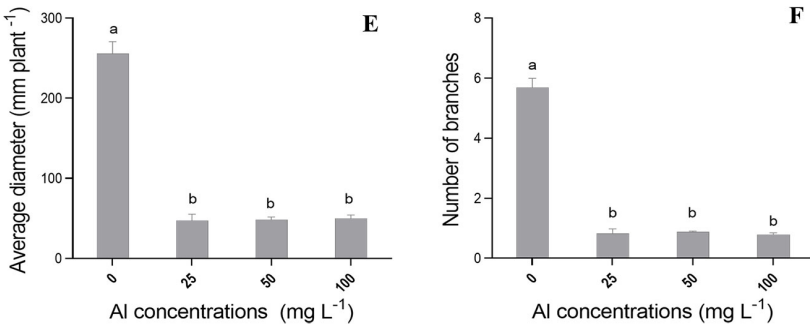

Fig. 3 - Mean values recorded for (A) largest root length increment (ILR), (B) root dry weight (RDW), (C) shoot dry weight (SDW), (D) root length, (E) root diameter, and (F) number of branches in $C$. fissilis seedlings subjected to different Al concentrations. Bars represent the mean \pm standard deviation. Different lowercase letters indicate significant $(p \leq 0.05)$ differences between treatment means after Tukey test.
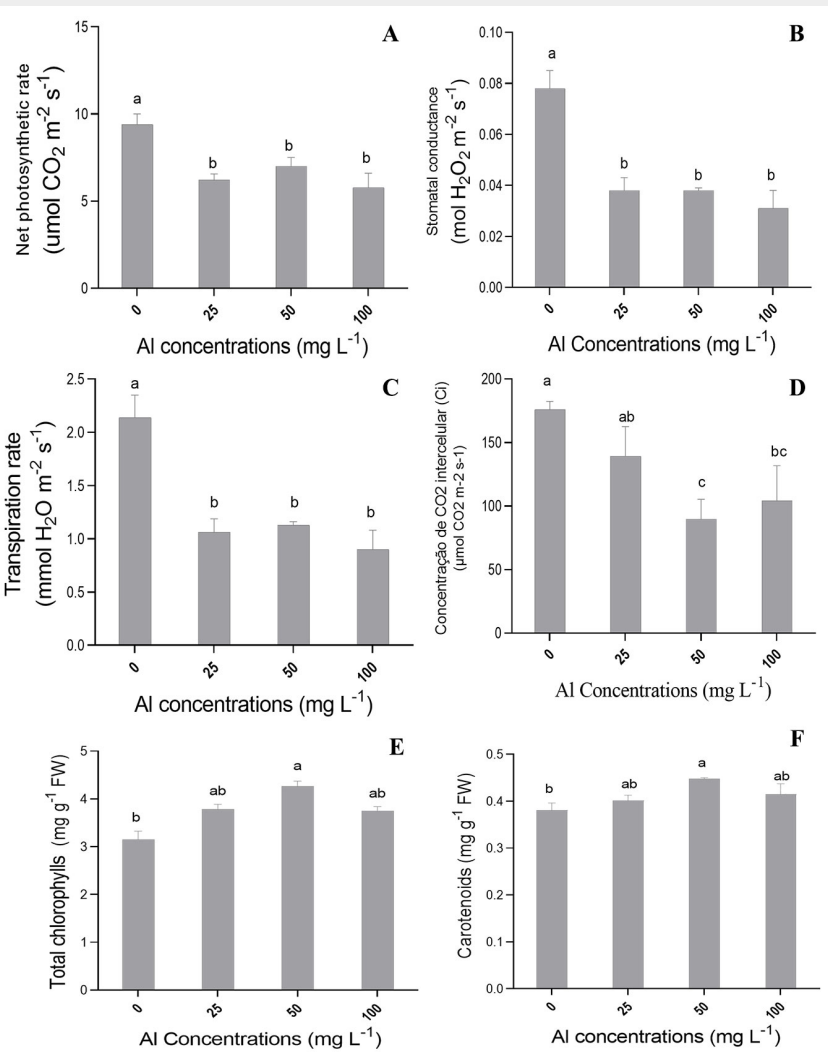

Fig. 4 - Mean values recorded for (A) net photosynthetic rate, (B) stomatal conductance (Gs), (C) transpiration, (D) intercellular $\mathrm{CO}_{2}$ concentration $\left(\mathrm{C}_{\mathrm{i}}\right)$, (E) total chlorophyll (total $\mathrm{Chl}$ ), and (F) carotenoids in $\mathrm{C}$. fissilis seedlings subjected to different $\mathrm{Al}$ concentrations. Bars represent the mean \pm standard deviation. Different lowercase letters indicate significant $(p \leq 0.05)$ differences between treatment means after Tukey test. differences $(p \leq 0.05)$ among different Al parison to the control treatment (Fig. 3A). treatments (different $\mathrm{Al}$ concentrations) In addition, seedlings grown at Al concenon most growth-related morphological var- trations of 25 and $50 \mathrm{mg} \mathrm{l}^{-1}$ showed a signifiiables.

The ILR (increment of the largest root) variable showed the lowest mean (15.93 $\mathrm{cm})$ at Al concentration of $100 \mathrm{mg} \mathrm{L}^{-1}$, which was significantly $(p<0.05)$ different from that recorded for control seedlings (42.97 cm - Fig. 3A). Al concentration of $100 \mathrm{mg} \mathrm{L}^{-1}$ reduced ILR by $37.07 \%$, in comcant ILR reduction. On the other hand, we found no significant differences in height growth (SI) of $C$. fissilis seedlings, regardless of Al concentrations (data not shown). Shoot dry weight (SDW - Fig. 3C) and root dry weight (RDW - Fig. 3B) also had the lowest means at the highest Al concentration (100 $\mathrm{mg} \mathrm{l}^{-1}$ ), in comparison to the control treatment. However, SDW and RDW means at Al concentrations of 25 and $50 \mathrm{mg} \mathrm{l}^{-1}$ did not differ from those recorded for the control treatment (Fig. 3).

The application of different Al concentrations had the most severe effects on seedling root length (Fig. 3D), root diameter (Fig. 3E) and number of branches (Fig. 3F), in comparison to the control treatment. The highest means recorded for the above variables were observed in the control

Tab. 2 - Mean values recorded for superoxide dismutase (SOD) enzyme activity, guaiacol peroxidase enzyme (POD) activity, hydrogen peroxide content, and membrane lipid peroxidation in the shoot and roots of $C$. fissilis seedlings subjected to different $\mathrm{Al}$ concentrations. Data represent the mean \pm standard deviation. Different letters in rows indicate significant $(p \leq 0.05)$ differences between treatment means after Tukey test.

\begin{tabular}{|c|c|c|c|c|c|}
\hline \multirow{2}{*}{ Variable } & \multirow{2}{*}{ Compartment } & \multicolumn{4}{|c|}{ Treatment (Al concentration) } \\
\hline & & $0 \mathrm{mg} \mathrm{l}^{-1}$ & $25 \mathrm{mg} \mathrm{l}^{-1}$ & $50 \mathrm{mg} \mathrm{l}^{-1}$ & $100 \mathrm{mg} \mathrm{l}^{-1}$ \\
\hline \multirow{2}{*}{$\begin{array}{l}\text { SOD activity } \\
\left(\mathrm{U} \mathrm{mg}^{-1} \text { protein }\right)\end{array}$} & Shoot & $365.5 \pm 4.5^{c}$ & $500.91 \pm 7.2^{b}$ & $522.1 \pm 6.0^{b}$ & $1180.5 \pm 9.6^{a}$ \\
\hline & Root & $267 \pm 4.8^{c}$ & $342.56 \pm 2.8^{b}$ & $388.5 \pm 1.6^{b}$ & $549.1 \pm 3.1^{a}$ \\
\hline \multirow{2}{*}{$\begin{array}{l}\text { POD activity } \\
\text { (U mg } \text { mprotein) }^{-1} \text { prote }\end{array}$} & Shoot & $245.7 \pm 9.7^{\mathrm{a}}$ & $192.22 \pm 18^{b}$ & $148.8 \pm 7.7^{c}$ & $143.8 \pm 11^{c}$ \\
\hline & Root & $1090 \pm 8.3^{\mathrm{a}}$ & $1202 \pm 8.7^{a}$ & $1207 \pm 12.6^{a}$ & $1203 \pm 20^{a}$ \\
\hline \multirow{2}{*}{$\begin{array}{l}\mathrm{H}_{2} \mathrm{O}_{2} \\
\left(\mu \mathrm{mol} \mathrm{g}{ }^{-1} \mathrm{FW}\right)\end{array}$} & Shoot & $0.55 \pm 0.02^{c}$ & $0.87 \pm 0.01^{b}$ & $1.10 \pm 0.06^{a}$ & $0.87 \pm 0.04^{b}$ \\
\hline & Root & $0.07 \pm 0.00^{c}$ & $0.12 \pm 0.01^{b}$ & $0.15 \pm 0.00^{b}$ & $0.22 \pm 0.02^{\mathrm{a}}$ \\
\hline \multirow{2}{*}{$\begin{array}{l}\text { MDA } \\
\text { (nmol mg }{ }^{-1} \text { protein) }\end{array}$} & Shoot & $0.06 \pm 0.00^{b c}$ & $0.04 \pm 0.00^{c}$ & $0.07 \pm 0.00^{b c}$ & $0.13 \pm 0.00^{\mathrm{a}}$ \\
\hline & Root & $0.03 \pm 0.00^{b}$ & $0.02 \pm 0.00^{b}$ & $0.03 \pm 0.00^{b}$ & $0.06 \pm 0.00^{\mathrm{a}}$ \\
\hline
\end{tabular}


treatment (Fig. 3). Only the highest Al concentration (100 $\mathrm{mg} \mathrm{l}^{-1}$ of $\mathrm{Al}$ ) had negative effect on root volume.

There was significant effect $(p \leq 0.05)$ of different Al concentrations on most photosynthetic variables analyzed in the present study. Aluminum concentrations of 25,50 and $100 \mathrm{mg} \mathrm{H}^{-1}$ negatively affected net $\mathrm{CO}_{2}$ assimilation rate $(A-$ Fig. $4 A)$, stomatal conductance (Gs - Fig. 4B), and transpiratory rate ( $E-$ Fig. $4 C$ ) in $C$. fissilis seedlings in comparison to the control treatment. The highest means for these variables were recorded in the control treatment. The lowest mean internal $\mathrm{CO}_{2}$ concentrations $\left(C_{\mathrm{i}}\right)$ were recorded at $\mathrm{Al}$ concentrations of 50 and $100 \mathrm{mg} \mathrm{H}^{-1}$ (89.858 and $104.200 \mu \mathrm{mol} \mathrm{CO} \mathrm{Cm}^{-2} \mathrm{~s}^{-1}$, respectively - Fig. 4D). All tested Al concentrations promoted a significant increase in water use efficiency (WUE - data not shown) in comparison with the control. On the other hand, there was no significant effect between treatments on Rubisco carboxylation efficiency $\left(A / C_{i}\right.$ - data not shown).

Significant effects $(p \leq 0.05)$ of different Al concentrations on biochemical variables assessed were also observed. Indeed, 50 $\mathrm{mg} \mathrm{I}^{-1}$ of $\mathrm{Al}$ promoted significant increase in total chlorophyll (Fig. 4E) and carotenoid contents in comparison to the control (Fig. $4 \mathrm{~F})$. Superoxide dismutase (SOD) activity in the shoot and roots of seedlings showed a significant increase at all tested Al concentrations (Tab. 2).

Lower guaiacol peroxidase (POD) activity was observed in the shoot of seedlings subjected to Al concentrations of 25,50 and $100 \mathrm{mg} \mathrm{l}^{-1}$, in comparison to the control (Tab. 2). On the other hand, there was not significant difference in POD activity in the roots, regardless of the $\mathrm{Al}$ concentrations (Tab. 2).

The highest hydrogen peroxide $\left(\mathrm{H}_{2} \mathrm{O}_{2}\right)$ content was observed in the shoot and in the roots of plants subjected to all tested Al concentrations (Tab. 2).

Lipid peroxidation in the shoot and roots was significantly increased in plants subjected to the highest $\mathrm{Al}$ concentration (100 $\mathrm{mg} \mathrm{l}^{-1}-$ Tab. 2). On the other hand, lipid peroxidation in the shoot and roots of seed lings subjected to $\mathrm{Al}$ concentrations of 25 and $50 \mathrm{mg} \mathrm{l}^{-1}$ did not significantly differ from that of the control treatment (Tab. 2).

\section{Discussion}

\section{Cadmium}

Growth reduction in the shoot and roots is one of the main $\mathrm{Cd}$ toxicity symptoms in plants, leading to a decrease of biomass production in plants belonging to different species (Deng et al. 2014). However, shoot growth (SI - data not shown) was lesser affected than root growth in the present study (Fig. $1 \mathrm{~A}$ ) due to $\mathrm{Cd}$ addition to the nutrient solution. This could be attributed to the fact that roots are often in direct contact with contaminants (Huang et al. 2017), thus affecting the physiological response of plants to stress. Moreover, $\mathrm{Cd}$ is mostly retained in the roots and only smaller amounts are translocated to the shoots, whereby causing lesser damage to the latter organs (Hassan et al. 2020).

Root increment inhibition (Fig. 1A) induced by $\mathrm{Cd}$ was observed at concentrations of 50 and $100 \mu \mathrm{M}$, corroborating the results reported by Ullah et al. (2020) in Cicer arietinum L. cultivars subjected to high Cd stress $(50 \mu \mathrm{M})$. This response can be attributed to cell cytoskeleton microtubule depolymerization and to chromosomal aberration formation, which lead to lower mitotic activity of meristematic cells (He et al. 2017).

Changes in root morphology may be part of integrated signal response to metal stressors. In fact, a stroFig. 1g reduction in the length, diameter and number of root branches (Fig. 1D-F) were observed under the highest $\mathrm{Cd}$ stress level $(100 \mu \mathrm{M})$. These changes in root morphology under $\mathrm{Cd}$ stress may stem from changes in root development, such as reduced parenchymal cell and cortical tissue size, which decreased plants' resistance to radial water flows.

Although different $\mathrm{Cd}$ concentrations did not affect shoot growth (data not shown), a reduced shoot dry weight was observed (Fig. 1C). This may be due to the reduced stem diameter or the decreased number of leaves, which resulted in lower shoot dry weight production from cedar seedlings (Fig. 1C). In addition, reduced root growth, along with changes in root morphological variables (Fig. 1D-F), have also negatively affected the biomass production of cedar seedling, since smaller roots absorb lesser water and nutrient amounts.

Plants subjected to stress conditions adjust their relative biomass allocation in their organs, in a process known as allocation plasticity. They also change basic processes such as photosynthesis and respiration (Dhir et al. 2011). Photosynthetic ability in plants is mainly regulated by photochemical reactions, which enable energy production, gas exchange, as well as $\mathrm{CO}_{2}$ fixation and assimilation. However, $\mathrm{Cd}$ can damage plants' photosynthetic ability, induce oxidative stress, inhibit stomatal opening and reduce nitrate and iron absorption (Yang et al. 2015).

In this study, significant reductions in $\mathrm{CO}_{2}$ assimilation rate $(A-$ Fig. $2 A)$, stomatal conductance (Gs - Fig. 2B), and transpiration rate ( $E-$ Fig. $2 C$ ) was observed as $C d$ concentrations in nutrient solution increased. The most severe effect of $\mathrm{Cd}$ on these variables was recorded at $\mathrm{Cd}$ concentration of $100 \mu \mathrm{M}$. Decreased net assimilation rate (Fig. $2 \mathrm{~A}$ ) may be associated with limited $\mathrm{CO}_{2}$ diffusion to the Rubisco carboxylation site, due to decreased stomatal conductance (Fig. 2B). Heavy metal-related stress can lead to decreased stomatal conductance, thus limiting the photosynthetic ability (Huihui et al. 2020).

Cadmium decreases partial $\mathrm{CO}_{2}$ pressure in the stomata, which leads to stomatal closure and decreased transpiration. One of the harmful effects of $\mathrm{Cd}$ lies on calcium induction in the endoplasmic reticulum and vacuole. This process increases cation levels in the cytosol, which is associated with stomatal closure (Nogueira 2018). Thus, Cd affects stomatal opening and closure, mainly due to increased leaf osmotic potential and to direct $\mathrm{Cd}$ action on guard cells. In addition, Gs reduction (Fig. 2B) may occur due to root growth inhibition, which limits water absorption and leads to stomatal closure. Moreover, high chemical element concentration leads to metabolic decline, leaf turgidity loss and hydropassive stomatal closure (Sousa 2018). Therefore, the observed reduction in transpiration rates is directly linked to the reduction in assimilation rate and stomatal conductance (Fig. 2).

The highest water use efficiency (WUE) values (data not shown) were found at $\mathrm{Cd}$ concentrations of 100 and $50 \mu \mathrm{M}$, as the stress caused by $\mathrm{Cd}$ forced plants to close their stomata. This decreased the stomatal conduction (Fig. 2B) and led to areduced transpiration rate (Fig. $2 \mathrm{C}$ ), which in turn resulted in higher WUE.

The photosynthetic performance of seedlings is also affected by the pigments involved, such as total chlorophyll and carotenoids (Taiz et al. 2017). The observed increase in total chlorophyll and carotenoid contents in plants exposed to $\mathrm{Cd}$ concentration of $50 \mu \mathrm{M}$ (Fig. 2E-F) was not sufficient to counterbalance the reduction in photosynthetic performances due to $\mathrm{Cd}$ stress. This response may be associated with the fact that $\mathrm{Cd}$ stress impairs chloroplast structure and affects their stable binding to proteins, thus damaging the photosynthetic apparatus. In fact, Cd ions may change the activity center of enzymes and replace $\mathrm{Mg}^{2+}$ in the chlorophyll molecule (Zhang et al. 2019), decreasing the light harvesting ability of chlorophyll and affecting the activity of enzymes associated with chlorophyll synthesis. This process has negative effects on photosynthetic variables, leading to the reduction of seedling dry weight (Zhang et al. 2019). These inhibitory effects may also be associated with indirect $\mathrm{Cd}$ interaction with micronutrients, which act as cofactors for enzymes, pigments and structural components of the photosynthetic apparatus.

Carotenoid contents in seedlings subjected to $50 \mu \mathrm{M}$ of $\mathrm{Cd}$ have increased to protect the photosynthetic apparatus and avoid singlet oxygen formation (reactive oxygen species - ROS). This occurs because carotenoids are non-enzymatic antioxidants acting as photoprotective pigments in the photosynthetic system by suppressing ROS and free radicals' formation (Reyes-Díaz et al. 2009). Increased carotenoid content is the result of a natural strategic defense mechanism to combat the toxic effect of oxidative stress generated under $\mathrm{Cd}$ stress. 
Plants are equipped with a natural defense system made by enzymatic and nonenzymatic antioxidants, which act as a protection from the oxidative damage induced by different environmental stress types (Hassan et al. 2020). Indeed, ROS can be produced through different routes, such as the imbalance in electron transport chains of chloroplasts and mitochondria. Cadmium can lead to ROS generation by inducing chloroplast disturbance (Yang et al. 2015). Antioxidant enzymes such as superoxide dismutase (SOD) and guaiacol peroxidase (POD), play a key role in maintaining homeostasis in plant cells (Zhang et al. 2019) by maintaining cellular redox status and prevent damage caused by ROS accumulation. In particular, SOD plays crucial role in removing the radical $\mathrm{O}_{2}^{-}$, whose decomposition is always followed by $\mathrm{H}_{2} \mathrm{O}_{2}$ production which acts as oxidizer and reducer (Weifeng et al. 2018). The results of this study showed that SOD activity in the shoot gradually increased as Cd concentrations in the nutrient solution also increased (Tab. 1), as a consequence of the activation of the existing enzyme stock by the increased free radical production (Hassan et al. 2020). The increased SOD activity in the shoot (Tab. 1) indicated that free radicals resulting from stress were neutralized via the formation of $\mathrm{H}_{2} \mathrm{O}_{2}$. However, high $\mathrm{H}_{2} \mathrm{O}_{2}$ accumulation is extremely harmful to the cellular metabolism, and POD converts $\mathrm{H}_{2} \mathrm{O}_{2}$ into water and oxygen. POD plays an essential role in providing tolerance to plants exposed to unfavorable conditions (Li et al. 2014). In this study we observed an increased POD activity in the shoot, which may due to the increase in $\mathrm{H}_{2} \mathrm{O}_{2}$ released by SOD activity as a consequence of Cd stress (Tab. 1). On the other hand, POD activity inhibition was detected in the roots of seedlings subjected to all tested $\mathrm{Cd}$ concentrations (Tab. 1). This may be associated with a decreased enzyme synthesis or with changes in the assembly of its subunits (Xin et al. 2019). Excessive metal accumulation can inhibit enzymes by binding to catalytic active groups or by causing protein denaturation. Thus, POD activity often decreases when stress exceeds plants' regulatory capacity (Zhang et al. 2020). The decrease in POD activity suggests a likely delay in ROS removal, which implies an increase in lipid peroxidation which contributes to seedling growth inhibition.

Nonetheless, the increased POD activity in the shoot, mainly at $\mathrm{Cd}$ concentrations of 50 and $100 \mu \mathrm{M}$, was unsuccessful in counteracting the $\mathrm{H}_{2} \mathrm{O}_{2}$ accumulation (Tab. 1), as $\mathrm{H}_{2} \mathrm{O}_{2}$ content in the shoot significantly increased as $\mathrm{Cd}$ concentrations increased in the nutrient solution (Huang et al. 2017). According to Weifeng et al. (2018), the high $\mathrm{H}_{2} \mathrm{O}_{2}$ rates observed under $\mathrm{Cd}$ stress were likely accountable for lipid peroxidation, as indicated by the excessive malondialdehyde (MDA) accumulation. MDA is an oxidized product of membrane lipids; it accumulates in plants exposed to oxidative stress. Therefore, MDA concentration in plants is often seen as an indicator of lipid peroxidation, as well as of the level of oxidative stress (Huang et al. 2017). In this study, the highest MDA content observed in the shoot was found at $\mathrm{Cd}$ concentrations of 25,50 and $100 \mu \mathrm{M}$ (Tab. 1), while the highest MDA content in the seedling roots was recorded at $\mathrm{Cd}$ concentrations of 25 and $100 \mu \mathrm{M}$. Thus, our results indicate that different $\mathrm{Cd}$ concentrations can change the original balance of plasma membrane permeability, as well as increase ROS production and induce antioxidant protein expression as adaptive response to neutralize ROS excess and minimize damage.

\section{Aluminum}

Root growth in this study was significantly inhibited by aluminum in the nutrient solution, especially at concentrations of 50 and $100 \mathrm{mg} \mathrm{l}^{-1}$ (Fig. 3A). On the other hand, shoot growth was lesser affected by $\mathrm{Al}$, regardless of the tested concentrations (data not shown). Indeed, roots are one of the organs mostly sensitive to Al, resulting in the inhibition of main axis elongation, as well as in the limited development of lateral roots, which leads to short and poorlydeveloped root system (Bose et al. 2015, Zhao et al. 2017).

In addition, different $\mathrm{Al}$ concentrations significantly reduced the length, diameter and number of branches in cedar seedling roots (Fig. 3D-F). This is likely due to the strong binding of Al to negatively charged carboxylic groups on roots' cortical and epidermal cell walls, thus changing ions binding and distribution in the apoplast and directly affecting root growth (Dorneles et al. 2016). Also, changes in morphological characteristics of roots can be caused by apoplastic lesions and interactions in root plasma membrane (Zhou et al. 2017, Zhao et al. 2017), which leads to deficient mineral nutrient and water acquisition (Guo et al. 2017).

Root growth inhibition and changes in root morphological variables negatively affected root and shoot biomass production in plants exposed to $100 \mathrm{mg} \mathrm{l}^{-1}$ of $\mathrm{Al}$ (Fig. 3). The aluminum translocation to the shoot may have negatively influenced the formation and growth of these organs, which implied reduced photosynthetic rate (Fig. 4A) and lower biomass production (Guo et al. 2018). Moreover, Al stress may be responsible for determining structural changes in plant tissues (Mota et al. 2020) and impairing the functioning of photosynthetic apparatus, as suggested by the low net photosynthetic rates ( $A$ - Fig. 4A), associated with the decrease in stomatal conductance (Gs - Fig. 4B) and internal $\mathrm{CO}_{2}$ concentration ( $C_{i}-$ Fig. $\left.4 \mathrm{D}\right)$ observed in seedlings under Al stress.

Aluminum may change stomatal behavior and directly influence stomatal closure (Cárcamo et al. 2019); consequently, it inhibits plant transpiration ( $E-$ Fig. $4 C$ ) and increases water use efficiency, especially at the highest $\mathrm{Al}$ concentration (100 $\left.\mathrm{mg} \mathrm{l}^{-1}\right)$. A possible explanation is that higher Al concentrations in the nutrient solution enhances cuticle and epicuticular wax development and leads to higher WUE (Tabaldi et al. 2011). In addition, seedlings exposed to Al showed reduced stomatal conductance, which may also result in higher WUE. Photosynthetic pigments are extremely sensitive to stress caused by toxic metals and can be used as reliable markers of stress caused by these metals (Anjum et al. 2017). Aluminum concentration of $50 \mathrm{mg} \mathrm{l}^{-1}$ led to significant increase in total chlorophyll content in comparison to the control (Fig. 4E). However, the increase in photosynthetic pigment contents did not hinder a decrease in photosynthesic rates and, consequently, in dry biomass production (Fig. 3B-C). Moreover, high concentrations of Al have been reported to damage thylakoid membranes and replace compounds in the chlorophyll metabolic pathway (Marques et al. 2018). Aluminum can also affect chlorophyll biosynthesis by inhibiting $\delta$ aminolavulinic acid dehydratase activity, which accounts for chlorophyll molecule and cytochrome formation (Cunha Neto et al. 2020). Therefore, higher concentrations of this ion can change chlorophyll and carotenoid composition, which can limit plant metabolic potential (Mendes et al. 2018).

Al concentration of $50 \mathrm{mg} \mathrm{l}^{-1}$ has also promoted significant increase in carotenoid content in C. fissilis seedlings compared to control (Fig. 4F). Carotenoids play an essential role in protecting the photosynthetic apparatus against the harmful effects of light and oxygen by dissipating the excess of light in the form of heat in antenna pigment complexes (Reyes-Díaz et al. 2009). However, whenever carotenoids fail to dissipate ROS, antioxidant enzymes such as SOD and POD dismute ROS and maintain the cell homeostasis. In this study, we observed a gradual SOD activity increase in the shoot and roots as Al concentrations increased (Tab. 2). This suggests that plants' ability to detoxify ROS was positively regulated (Zhao et al. 2017). However, long-term Al stress can overcome the antioxidant capability of plant tissues. This results in ROS overproduction, which can damage biological membranes, have negative effects on photosynthetic activity, reduce enzyme activity and, finally, lead to programmed cell death (Zhang et al. 2019).

The presence of aluminum at any concentration in the nutrient solution has significantly reduced POD activity in the shoot of cedar seedlings, but not in the roots (Tab. 2). Conversely, the increased SOD activity in seedling tissues indicated that free radicals were neutralized and detoxified as $\mathrm{H}_{2} \mathrm{O}_{2}$ (Tab. 2). This may explain the observed accumulation of $\mathrm{H}_{2} \mathrm{O}_{2}$, which is released as a product of SOD activity but not properly removed by POD activity in the 
shoot.

$\mathrm{H}_{2} \mathrm{O}_{2}$ also plays an important role in signal transduction during plant abiotic stress, since it acts as biomarker of tissue damage induced by ROS overproduction (Yusuf et al. 2016). However, excessive $\mathrm{H}_{2} \mathrm{O}_{2}$ accumulation can be extremely harmful, leading to lipid peroxidation and increased plasma membrane permeability. Indeed, Al can bind to phospholipids and/or change the fatty acid composition in the plasma membrane, reducing its fluidity and increasing its permeability, and ultimately leading to lipid peroxidation (Bose et al. 2015).

Lipid peroxidation in the shoot and roots has significantly increased at the highest $\mathrm{Al}$ concentration (100 $\mathrm{mg} \mathrm{l}^{-1}-$ Tab. 2). On the other hand, MDA contents in the roots of seedlings subjected to Al concentrations of 25 and $50 \mathrm{mg} \mathrm{L}^{-1}$ did not differ from that of control plants (Tab. 2). The higher MDA content observed at the highest Al concentration (100 $\mathrm{mg} \mathrm{L}^{-1}$ ) can be the direct effect of Al toxicity, as well as indicate oxidative stress in cedar seedlings, which can cause irreversible damage to plant tissue development and function in the long run.

Our results demonstrate that Cedrela fissilis can tolerate moderate Al concentrations in the growth medium. Aluminum tolerance mechanisms involve the exclusion via root organic acid exudation, changes in carbohydrate components of cell walls capable of binding $\mathrm{Al}$ in roots, as well as the uptake and subsequent sequestration either in the root or leaf cell vacuoles, where it is detoxified and sequestered (Kochian et al. 2015). Besides, symplasmic tolerance to internal Al is also achieved by complexing Al with several organic compounds such as citrate, malate, and oxalate, as well as by secreting or sequestering the resulting complexes in vacuoles through several membrane-localized transport proteins, or by activating enzymatic and non-enzymatic antioxidants.

\section{Conclusion}

The presence of cadmium in the nutrient solution has negatively affected morphophysiological and biochemical variables in Cedrela fissilis seedlings, hindering their growth. Therefore, the species is sensitive to the exposure to cadmium. On the other hand, it has tolerated high Al concentrations (up to $50 \mathrm{mg} \mathrm{l}^{-1}$ ), which may indicate its tolerance to this metal.

\section{Acknowledgements}

The authors are grateful to Coordenação de Aperfeiçoamento de Pessoal de Nível Superior (CAPES) and to Conselho Nacional de Desenvolvimento Científico e Tecnológico (CNPq) for providing financial support to the postgraduation programs, as well as to the Federal University of Santa Maria for providing the space and equipment for the current study.

\section{Authors' contributions}

CCK, MVMA, GSWO, DB, MB and LAT con- ceived and designed the experiments and analyzed the data; CCK, MVMA and GSWO carried out the physiological and photosynthetic analyses; CCK, MVMA, GSWO, DB, $M B$ and LAT carried out the biochemical analyses; CCK, MVMA and GSWO wrote the manuscript, and LAT revised it.

\section{References}

Anjum SA, Tanveer M, Hussain S, Ashraf U, Khanl, Wang $L$ (2017). Alteration in growth, leaf gas exchange, and photosynthetic pigments of Maize plants under combined cadmium and arsenic stress. Water, Air and Soil Pollution 28 (13): 1-12. - doi: 10.1007/s11270-016-3187-2

Beauchamp C, Fridovich I (1971). Superoxide dismutase: improved assays and an assay applicable to acrylamide gels. Analytical Biochemistry 44 (1): 276-287. - doi: 10.1016/0003-2697(71)9037 $0-8$

Bose J, Babourina O, Ma Y, Zhou M, Shabala S, Rengel Z (2015). Specificity of ion uptake and homeostasis maintenance during acid and aluminium stresses. In: "Aluminum Stress Adaptation in Plants" (Panda S, Baluška F eds). Signaling and Communication in Plants, vol. 24, Springer, Cham, Switzerland, pp. 229-251. - doi: 10.10 07/978-3-319-19968-9_12

Cárcamo MP, Reyes-Díaz M, Rengel Z, Alberdi M, Omena-Garcia RP, Nunes-Nesi A, InostrozaBlancheteau C (2019). Aluminum stress differentially affects physiological performance and metabolic compounds in cultivars of high bushblueberry. Scientific Reports 9 (1): 11275. - doi: 10.1038/541598-019-47569-8

Covre WP, Pereira WVDS, Gonçalves DAM, Teixeira OMM, Amarante $C B D$, Fernandes $A R$ (2020). Phytoremediation potential of Khaya ivorensis and Cedrela fissilis in copper contaminated soil. Journal of Environmental Management 268 (6): 110733. - doi: 10.1016/j.jenvman. 2020.110733

Cunha GOM, Almeida JA, Ernani PR, Pereira ER, Brunetto G (2018). Composition, chemical speciation and activity of ions in the solution of Brazilian acid soils. Revista Brasileira de Ciências Agrárias 13 (3): 01-10. - doi: 10.5039/agraria. v13iza5542

Cunha Neto AR, Ambrósio AS, Wolowski M, Westin TB, Govêa KP, Carvalho M, Barbosa S (2020). Negative effects on photosynthesis and chloroplast pigments exposed to lead and aluminum: a meta-analysis. Cerne 26 (2): 232-237. - doi: 10.1590/01047760202026022711

Deng G, Li M, Li H, Yin L, Li W (2014). Exposure to cadmium causes declines in growth and photosynthesis in the endangered aquatic fern (Ceratopteris pteridoides). Aquatic Botany 112: 2332. - doi: 10.1016/j.aquabot.2013.07.003

Dhir B, Sharmila P, Saradhi PP, Sharma S, Kumar $R$, Mehta $D$ (2011). Heavy metal induced physiological alterations in Salvinia natans. Ecotoxicology and Environmental Safety 74 (6): 16781684. - doi: 10.1016/j.ecoenv.2011.05.009

Dorneles AOS, Pereira AS, Rossato LV, Possebom G, Sasso VM, Bernardy K, Sandri RQ, Nicoloso FT, Ferreira PAA, Tabaldi LA (2016). Silicon reduces aluminum content in tissues and ameliorates its toxic effects on potato plant growth. Ciência Rural 46 (3): 506-512. - doi: 10.1590/0103-8478cr20150585
El-Moshaty FIB, Pike SM, Novacky AJ, Sehgal OP (1993). Lipid peroxidation and superoxide productions in cowpea (Vigna unguiculata) leaves infected with tobacco ringspot virus or southern bean mosaic virus. Physiological and Molecular Plant Pathology 43 (15): 109-119. - doi: 10.10 06/pmpp.1993.1044

Ferreira DF (2014). Sisvar: a guide for its bootstrap procedures in multiple comparisons. Ciência e Agrotecnologia 38 (2): 109-112. - doi: 10.159 o/S1413-70542014000200001

Giannopolitis CN, Ries SK (1977). Purification and quantitative relationship with water-soluble protein in seedlings. Journal of Plant Physiology 48: 315-318. - doi: 10.1104/pp.59.2.315

Goetten LC, Moretto G, Sturmer SL (2016). Influence of arbuscular mycorrhizal fungi inoculum produced on-farm and phosphorus on growth and nutrition of native woody plant species from Brazil. Acta Botanica Brasílica 30 (1): 9-16. doi: 10.1590/0102-33062015abb0175

Guo P, Li Q, Qi YP, Yang LT, Ye X, Chen HH, Chen LS (2017). Sulfur-mediated-alleviation of Aluminum-toxicity in Citrus grandis seedlings. International Journal of Molecular Sciences 18 (12): 2570. - doi: 10.3390/ijms18122570

Guo P, Qi YP, Cai YT, Yang TY, Yang LT, Huang ZR, Chen LS (2018). Aluminum effects on photosynthesis, reactive oxygen species and methylglyoxal detoxification in two Citrus species differing in aluminum tolerance. Tree Physiology 38 (10): 1548-1565. - doi: 10.1093/treephys/tpyo 35

Hassan MJ, Raza MA, Rehman SU, Ansar M, Gitari $H$, Khan I, Wajid M, Ahmed M, Shah GA, Peng Y, Li Z (2020). Effect of cadmium toxicity on growth, oxidative damage, antioxidant defense system and cadmium accumulation in two Sorghum cultivars. Plants 9 (11): 1575. - doi: 10.3390/plants9111575

He S, Yang X, He Z, Baligar VC (2017). Morphological and physiological responses of plants to Cadmium toxicity: a review. Pedosphere 27 (3): 421-438. - doi: 10.1016/S1002-0160(17)60339-4 Hiscox JD, Israelstam GF (1979). A method for the extraction of chlorophyll from leaf tissue without maceration. Canadian Journal of Botany 57: 1132-1334. - doi: 10.1139/b79-163

Hoagland DR, Arnon DI (1950). The water-culture method for growing plants without soil. Circ. 347, California Agricultural Experiment Station, University of California, Berkeley, CA, USA. pp. 32. [online] URL: http://www.cabdirect.org/cab direct/abstract/19500302257

Huang D, Gong X, Liu Y, Zeng G, Lai C, Bashir H, Zhou L, Wang D, Xu P, Cheng M, Wan J (2017). Effects of calcium at toxic concentrations of cadmium in plants. Planta 245 (5): 863-873. doi: 10.1007/s00425-017-2664-1

Huihui Z, Xin L, Zisong X, Yue W, Zhiyuan T, Meijun A, Yuehui Z, Wenxu Z, Nan X, Guangyu S (2020). Toxic effects of heavy metals $\mathrm{Pb}$ and $\mathrm{Cd}$ on mulberry (Morus alba L.) seedling leaves: photosynthetic function and reactive oxygen species (ROS) metabolism responses. Ecotoxicology and Environmental Safety 195: 1-11. - doi: 10.1016/j.ecoenv.2020.110469

Kochian LV, Piñeros MA, Liu J, Magalhaes JV (2015). Plant adaptation to acid soils: the molecular basis for crop aluminum resistance. Annual Review of Plant Biology 66 (1): 571-598. 
doi: 10.1146/annurev-arplant-043014-114822 Kubier A, Wilkin RT, Pichler T (2019). Cadmium in soils and groundwater: a review. Applied Geochemistry 108: 01-16. - doi: 10.1016/j.apgeochem. 2019.104388

Li Z, Peng Y, Zhang XQ, Ma X, Huang LK, Yan YH (2014). Exogenous spermidine improves seed germination of white clover under water stress via involvement in starch metabolism, antioxidant defenses and relevant gene expression. Molecules 19 (11): 18003-18024. - doi: 10.3390/ molecules191118003

Lichtenthaler HK (1987). Chlorophylls and carotenoids: pigments of photosynthetic biomembranes. In: "Methods in Enzimology", vol. 148 (Packer L, Douce R eds). Academic Press, London, UK, pp. 350-381. - doi: 10.1016/0076-6879 (87)48036-1

Loreto F, Velikova V (2001). Isoprene produced by leaves protects the photosynthetic apparatus against ozone damage, quenches ozone products, and reduces lipid peroxidation of cellular membranes. Plant Physiology 127 (9): 17811787. - doi: 10.1104/pp.010497

Marques DM, Silva AB, Mantovani JR, Pereira DS, Souza TC (2018). Growth and physiological responses of tree species (Hymenaea courbaril L., Peltophorum dubium (Spreng.) Taub. and Myroxylon peruiferum L. F.) exposed to different copper concentrations in the soil. Revista Árvore 42 (2): 1-11. - doi: 10.1590/1806-908820 18000200002

Mendes TP, Oliveira FL, Tomaz MA, Rodrigues WN, Teixeira AG (2018). Aluminum toxicity effect on the initial growth of yacon plantlets. Revista Ceres 65 (2): 120-126. - doi: 10.1590/00 34-730x201865020002

Mota LHS, Scalon SPQ, Dresch DM, Silva CJ (2020). Emergence and physiological behavior of provenances of Pinhão manso in function of level of aluminum. Bioscience Journal 36 (3): 702-712. - doi: 10.14393/BJ-v36n3a2020-41893

Nogueira GA (2018). Gas exchanges, growth and biochemical behavior in young plants of Paricá (Schizolobium amazonicum Huber ex Ducke) in different concentrations of Cadmium. PhD thesis, Graduate Program in Forest Sciences, Federal Rural University of the Amazon, Belém, Pará, Brazil, pp. 70.

Reyes-Díaz J, Alberdi M, Mora ML (2009). Shortterm Aluminum stress differentially affects the photochemical efficiency of photosystem II in highbush blueberry genotypes Marjorie. American Society for Horticultural Science 134 (1): 14-
21. - doi: 10.21273/JASHS.134.1.14

Silva D, Stuepp CA, Wendling I, HelmCV, Angelo AC (2020). Physiological and biochemical changes in Cedrela fissilis seeds during storage. Pesquisa Agropecuária Brasileira 55: 1-8. [online] URL: http://seer.sct.embrapa.br/index.ph p/pab/article/view/26842

Sousa JCM (2018). Fitorremediação de cádmio por Khaya ivorensis A. Chev. Modulações ecofisiológicas e Bioquímicas [Cadmium phytoremediation by Khaya ivorensis A. Chev. Ecophysiological and biochemical modulations]. Masters dissertation, Graduate Program in Forest Sciences, Federal Rural University of the Amazon, Belém, Pará, Brazil, pp. 73. [in Portuguese]

Tabaldi LA, Cargnelutti D, Castro GY, Gonçalves JF, Rauber R, Bisognin DA, Schetinger MRC, Nicoloso FT (2011). Effect of aluminum on the in vitro activity of acid phosphatases of four potato clones grown in three growth systems. Biologia Plantarum 55 (1): 178-182. - doi: 10.1007/s10 535-011-0026-6

Taiz L, Zeiger E, Moller IM, Murphy A (2017). Plant physiology and development ( $6^{\text {th }}$ edn). Artmed, Porto Alegre, Brazil, pp. 858. [online] URL: http://www.cabdirect.org/cabdirect/abstr act/20173165866

Ullah S, Khan J, Hayat K, Elateeq AA, Salam U, Yu B, Ma Y, Wang H, Tang ZH (2020). Comparative study of growth, cadmium accumulation and tolerance of three Chickpea (Cicer arietinum L.) cultivars. Plants 9 (3): 310. - doi: 10.3390/plants 9030310

Weifeng C, Yuanjie D, Guoqing $\mathrm{H}$, Xiaoying B (2018). Effects of exogenous nitric oxide on cadmium toxicity and antioxidative system in perennial ryegrass. Journal of Soil Science and Plant Nutrition 18 (1): 129-143. [online] URL: http://scielo.conicyt.cl/scielo.php?pid=S0718-95 162018005000601\&script=sci_abstract

Xin J, Zhao XH, Tan QL, Sun XC, Zhao YY, Hu CX (2019). Effects of cadmium exposure on the growth, photosynthesis, and antioxidant defense system in two radish (Raphanus sativus L.) cultivars. Photosynthetica 57 (4): 967-973. doi: 10.32615/ps.2019.076

Xu LM, Liu C, Cui BM, Wang N, Zhao Z, Zhou LN, Huang KF, Ding JZ, Du HM, Jiang W, Zhang SZ (2018). Transcriptomic responses to aluminum (Al) stress in maize. Journal of Integrative Agriculture 17 (9): 1946-1958. - doi: 10.1016/S2095-31 19(17)61832-X

Yan A, Wang Y, Tan SN, Mohd Yusof ML, Ghosh $S$, Chen Z (2020). Phytoremediation: a promis- ing approach for revegetation of heavy metalpolluted land. Frontiers in Plant Science 11: 359. - doi: 10.3389/fpls.2020.00359/full

Yang Y, Li X, Yang S, Zhou Y, Dong C, Ren J, Sun $X$, Yang $Y$ (2015). Comparative physiological and proteomic analysis reveals the leaf response to Cadmium-induced stress in poplar (Populus yunnanensis). PLoS One 10 (9): e0137396. - doi: 10.1371/journal.pone.0137396

Yusuf M, Khan TA, Fariduddin Q (2016). Responses of photosynthesis, stress markers and antioxidants under aluminium, salt and combined stresses in wheat cultivars. Cogent Food and Agriculture 2: 1216246. - doi: 10.1080/23311 932.2016.1216246

Zeraik AE, Souza FS, Fatibello-Filho O (2008). Desenvolvimento de um spot test para o monitoramento da atividade da peroxidase em um procedimento de purificação [Spot test development to monitor peroxidase activity in purification procedure]. Química Nova 31 (4): 731734. [in Portuguese] - doi: 10.1590/S0100-40422 008000400003

Zhang HH, Xu N, Teng ZY, Wang JR, Ma S, Wu X, Li X, Sun GY (2019). 2-Cys Prx plays a critical role in scavenging $\mathrm{H}_{2} \mathrm{O}_{2}$ and protecting photosynthetic function in leaves of tobacco seedlings under drought stress. Journal of Plant Interactions 14 (1): 119-128. - doi: 10.1080/17429145.20 18.1562111

Zhang $\mathrm{T}$, Hong $\mathrm{M}$, Wu M, Chen B, Ma Z (2020). Oxidative stress responses to cadmium in the seedlings of a commercial seaweed Sargassum fusiforme. Acta Oceanologica Sinica 39 (10): 147-154. - doi: 10.1007/s13131-020-1630-0

Zhao X, Chen Q, Wang Y, Shen Z, Shen W, Xu X (2017). Hydrogen-rich water induces aluminum tolerance in maize seedlings by enhancing antioxidant capacities and nutrient homeostasis. Ecotoxicology and Environmental Safety 144: 369-379. - doi: 10.1016/j.ecoenv.2017.06.045

Zhou D, Yang Y, Zhang J, Jiang F, Craft E, Thannhauser TW, Kochian LV, Liu J (2017). Quantitative ITRAQ proteomics revealed possible roles for antioxidant proteins in Sorghum Aluminum tolerance. Frontiers in Plant Science 7: 2043. doi: 10.3389/fpls.2016.02043/full

Zhu Z, Wei G, Li J, Qian Q, Yu J (2004). Silicon alleviates salt stress and increases antioxidant enzymes activity in leaves of salt-stressed cucumber (Cucumis sativus L.). Plant Science 167 (3): 527-533. - doi: 10.1016/j.plantsci.2004.04.020 